\title{
LAND GOVERNANCE AT THE CROSSROADS
}

\section{A Review of Afghanistan's Proposed New Land Management Law}

\section{Contents}

1. Introduction..........2

2. Assessment of the Law. ....

3. Proposed

Amendments to the Land Law. ... 9

4. Testing the Changes against the National Land Policy. 22

5. Conclusions. 24

6. Recommendations. . 24

\begin{abstract}
About the Author
Liz Alden Wily is an independent political economist who specialises in land tenure issues. She conducts research and provides technical advice to governments and programmes, mainly in post-conflict states.
\end{abstract}

\section{Acronyms \\ ARAZI Afghanistan Land Authority \\ LML Land Management Law \\ NLP National Land Policy}

Current as of August 2012

\section{Executive Summary}

Afghanistan's longstanding Land Management Law, last revised in 2008, is again under review. More than 100 amendments had been formally proposed by mid-2012. So far the proposed changes are mainly editorial and do not reform problematic fundamentals of the law. Some important issues still requiring urgent attention include that:

1) The system for establishing and formalising rights remains remote from the majority and loopholes that make the system corruptible are not closed.

2) The pledges of the National Land Policy of 2007 are not absorbed.

3) The land rights of vulnerable population sectors are not directly protected.

4) The conflict of interest that arises when courts issue land documents and are then expected to resolve disputes arising from them is not removed.

5) Fundamental structural problems that sustain conflict among communities and ethnicities over land claims are not sufficiently addressed. This particularly affects how real property is defined. The proposed amendments still make common properties that are owned customarily by rural communities invisible and thus vulnerable to wrongful classification as open access public lands or as government property, which the state can then allocate to whoever it pleases.

6) Land administration remains unduly over-centralized, unaccountable to ordinary Afghans, and overly-dependent upon presidential dictate.

7) Opportunities to devolve basic functions of Iand governance to grassroots levels are ignored and are out of sync with wider decentralization policies.

8) Measures introduced against land grabbing lack bite. 
However, the amount of time invested in the proposed amendments suggests that the Afghan government is serious about reform. Some limitations in the proposed amendments are unintentional. Others result from insufficiently taking on board the changed conditions of the time or the directives of well-thought-through policy change over recent years, affecting both urban and rural land holding. Other shortfalls in redrafting so far reflect undue caution in tackling the hard conflict-inducing constraints head-on, or uncertainty regarding how to overcome these. Still, the new Afghanistan
Land Authority, which is mandated to lead the preparation of the new Land Management Law, is known to be refreshingly open to discussion. Through public consultations and submissions the agency deserves all possible assistance to take steps toward a modern, democratic and pro-majority land administration system. This critique is offered in this spirit.

For more detail of the proposed changes and how they compare to the National Land Policy, see the tables in Sections 3 and 4. Recommendations are found in Section 6.

\section{Introduction}

This is the first of several related briefing papers by the Afghanistan Research and Evaluation Unit, each considering a single issue affecting land and property relations in Afghanistan. This paper critiques proposed changes to the Land Management Law 2008 that were compiled until early this year. The Afghanistan Land Authority (ARAZI) is now conducting public consultations and many more changes are expected. This analysis is designed to constructively contribute to this process and the wider debate on land governance in Afghanistan.

\subsection{Does the Land Management Law Matter?}

First, it is useful to briefly consider the relevance of the Land Management Law (LML) at this time in Afghanistan. Amendments to the land law may seem irrelevant in conditions of weak rule of law. Thousands of land parcels continue to change hands in illegal ways while millions of parcels are held or transacted outside the legal sector. Reference by the courts to existing statutes is scant, most judges preferring a single instrument as guide: the Civil Code 1977.

Nor does remedy seem to lie wholly in extralegal norms and procedures. Customary regimes and thriving alternative dispute mechanisms are also touched by accusations of inj ustice and corruption. Parts of the country are meanwhile under the control of actors who make or influence land decisions on other grounds again. So how can changing the terms of the main land law make a difference?
This paper takes the position that how real property is identified in the first instance and how land relations are formally governed in law are themselves critical drivers to improved rule of land law. That is, rule of law is itself of reduced value if what the law says is unfair, exclusive to better-off groups, unworkable in practice, or not accountable to rightful landholders and land users. Citizens also need a clear set of legal paradigms that they can use to challenge abuse of their rights.

\subsection{Why the Land Management Law is important}

The LML has a special place in Afghanistan land law. It is not the only land law but it is the nearest Afghans have to a basic national land statute. ${ }^{1}$ The LML covers such fundamental subjects as how private property is defined, how private properties are identified and their ownership formalised in legal ways, how the government may lease lands to investors or allocate it to landless persons, and how state power over land holding is vested. In addition, implicit policies are expressed through its provisions.

Other laws cover more specific subjects such as the compulsory purchase of private land for public purposes, land survey procedure, foreign access to land, powers of municipalities over urban domains and how rangeland, forest, and mineral and water resources are owned,

\footnotetext{
1 Land Management Law (Official Gazette no. 958), 2008 (SY 1388).
} 
used and governed. ${ }^{2}$ The president has also issued more than ten decrees since 2002 that alter land law in some way. These raise questions of precedence when their terms are inconsistent with more substantial laws like the LML. This mostly involves Decree 83 of 2003 (the Decree on Immovable Property), which may be interpreted as unconstitutional in its diminishment of untitled land rights and dangerously undermining of critical distinctions between government and public land. ${ }^{3}$ This and several other decrees also raise questions of legal procedure, it being the position of the author and others that decrees on subjects as important as land rights cannot be passed off as administrative orders and not subjected to parliamentary scrutiny and approval. While the issues of substance that Decree 83 and others raise can easily be resolved through the redrafting of the LML and the firm repealing of related outstanding interim decrees, questions remain as to legal procedure and the scope of land matters that may be presidentially directed without parliamentary discussion. It is suggested later that some limitations may be worth inscribing in the redrafted LML.

While the $L M L$ is pivotal in the canon of Afghanistan's state law, it is not comprehensive. On matters of tenure, the law is weak in its handling of majority rights that derive through customary law. Its focus remains unduly upon rural property even though urban tenure and governance issues are also pressing. Other criticisms have been levied against the law over the last decade, particularly on institutional and procedural gaps. ${ }^{4}$

2 For reviews of other laws refer to Liz Alden Wily, "Land Rights in Crisis" (Kabul: AREU, 2003); Conor Foley, "A Guide to Property Law in Afghanistan" (Kabul: Norwegian Refugee Council, 2005); and Yohannes Gebremedhin, "Land Tenure and Administration in Rural Afghanistan: Legal Aspects" (Kabul: Asian Development Bank/ DFID, 2007).

3 Decree on Immovable Property, No. 83, 2003 (SY 1382).

4 Most recently including LARA Project, "Property Assessment: Land Reform in Afghanistan (LARA)" (Kabul: USAID, September 2011); and Patrick McAuslan, "Land Management Law of the Islamic Republic of Afghanistan: A Commentary" (Kabul: The World Bank, 2011). Also refer to Gebremedhin, "Land Tenure and Administration." Their recommendations are taken into account in this critique, in particular McAuslan, who took time to lay out suggested text on topics not yet considered by the drafters of the new LML: matters of adjudication, urban regularisation and

\subsection{The property-tax origins of the LML}

The LML 2008 has origins in the Law of Preparation of Statistics and Registration of Property and Rights of Sale of Excess Land in Afghanistan, 1960. At the time, "excess land" referred to land outside the property tax system. Capturing information about land holding in taxable ways has remained an objective of the law ever since, although this lapsed in practice during the conflict years. The law itself has been variously replaced, with additions, omissions and changes, in laws of 1965, 1975, 1981, 1986, 1988 and 2000, along with amendments and supplementary decrees. In the process some subjects (such as cadastral survey and rights to pasture lands) have been separated off into laws of their own. Compulsory purchase of private property for public purpose has had its own law since 1935, and its fundamental principle that fair compensation must be paid for such takings has remained unchanged although provisions for appeal along with some other rights have been curtailed. ${ }^{5}$ In terms of national land laws, only property tax decrees were introduced earlier. ${ }^{6}$

\subsection{A declining social agenda}

Many of the subjects described above have not been significantly altered over the last halfcentury, particularly since the Land Survey and Statistics Law, 1965. This was a law of 70 articles in nine chapters. In its current pre-consultation version, the LML contains 111 articles in 12 chapters. New chapters introduced since the 1990s address restitution and commercial leasing of lands, and now land grabbing.

The most marked change in land law in Afghanistan since the 1960s has been its social agenda and the shift to compulsory redistribution of farmlands and then to the restitution of these

resettlement, and development of a unified registration procedure.

5 Law for Appropriation of Property for Public Welfare in Afghanistan, 1935 (SY 1314), building upon the principle of compensation provided in the Constitution of 1923.

6 Part of King Amanullah's modernisation reforms focused on raising tax on land and livestock, accounting for five eighths of his domestic revenues in 1926. B. Rubin, The Fragmentation of Afghanistan: State Formation and Collapse in the International System (New Haven: Yale University Press, 2002), 55. 
same lands to the original landlords. In this context, the changing meaning of "excess land" between 1960 and 2012 is indicative. In 1960 and 1965, this meant land held by a farmer but for which he was not paying taxes. By the land reform law of 1975, "excess land" referred to arable landholdings above a permitted ceiling, which the state could forcibly redistribute to landless farmers having paid compensation to the owner. In the more rigorously redistributive law of 1978 under the communist regime, the ceiling fell to 30 jeribs ( $6 \mathrm{ha}$ ) of first grade arable land and the government did not need to pay compensation to the owner. This excess was distinct from "surplus land," which now meant land above the area indicated in a valid land document, irrespective of taxes paid on it. A new version of the LML in 1988 raised the ceiling to 100 jeribs (20 ha); ceilings were effectively abandoned in the laws of the 1990s and disappeared entirely in the Taliban-issued land law of 2000. At the same time, restitution of lands taken since the Saur Revolution of 1978 replaced legal commitments to redistribution. ${ }^{7}$ Allocation of land to landless thus became a right of the state, not a duty. This is retained in both the 2008 law and the draft amendments of today.

While private lease of state land was always possible, this was addressed in greater detail by the 2000 law and much expanded in President Karzai's reissue of the law in 2008. Indeed, this was sufficiently emphasised to have an objective inserted in the law for the "Creation of a favourable environment for private sector investment in land" (Article 2[8]). Most amendments to the law in 2008 were on this subject. ${ }^{8}$ Lease terms and leasable areas were expanded (up to 90 years for virgin and barren lands), and foreigners were included as eligible lessees. ${ }^{9}$ Interestingly, current proposals seek to

\footnotetext{
7 Alden Wily, "Land Rights in Crisis," 41-50; Gebremedhin, "Land Tenure and Administration," 15-17.

8 Refer to Articles 61-83 in the 2000 LML and Articles 59-81 in the 2008 version.

9 Compare Article 64 or 65 of 2008 (depending on version) with Article 69 of the 2000 law. In fact, President Karzai had already facilitated foreign land access through the Law on Domestic and Foreign Private Investment in Afghanistan, Decree No. 134 (Official Gazette no. 803), 2002 (SY 1381), which permitted foreign investors to lease lands for up to 30 years. The Decree on the Transfer of Government Property, Decree no. 89, 2003 (SY 1392), made surplus government
}

remove this objective of the law and reduce the size of lands that may be leased.

\section{Undue enhancement of state powers}

Another key change concerns properties that are neither covered by a legal deed nor are entered into the Books of Ownership and Taxation, established in the 1970s. As most properties are not evidenced by a formal deed, and as the books have not been systematically updated since 1978, this affects the maj ority of Afghans, mainly the poor. Article 9 of the Taliban's land law of 2000 established visible occupation of lands and the testimony of neighbours as sources of evidence of ownership. The amendments of 2008 inserted an additional requirement that the holder must have possessed the land for more than 35 years (i.e. since 1973). While no doubt designed to limit claims of recent land grabbers and unlawful occupiers, this has the effect of limiting all claims to lands acquired since 1973, an unreasonable demand in any circumstance let alone in a country that has seen such altered settlement patterns. Hand in hand with the mentioned Decree 83 of 2003, all such properties are currently considered to be state property. However well intentioned, this may be seen as an undue land grab by the state. Nor is there currently a right of appeal against this.

\subsection{Uncertain status of the 2008 law}

The status of the LML 2008 is not actually crystal clear since the amendments it made to the LML 2000 were approved by the Council of Ministers but without parliamentary confirmation. Neither the 2004 Constitution (Article 97) nor the 1999 Regulation on the Procedure for Preparation and Proposing of Legislative Documents ${ }^{10}$ are clear on what occurs when the Wolesi Jirga (lower house of parliament) fails to approve or reject a decree put before it by the Council of Ministers.

land available to the High Commission for Investment for allocation to investors, and prevented ministries from selling, leasing or renting out properties. The Private Investment Law, 2003 (amended 6 December 2006), permitted leases for terms of up to 50 years (Article 21).

10 Official Gazette no. 787, 1999 (SY 1378). 


\section{Assessment of the Law}

The assessment in this paper is made mainly from the perspective of poor Afghans. The main indicators used include whether the law is pro-poor and pro-majority; how far it takes into account mechanisms of land allocation and security that stem from local, communitybased norms; whether the law is just; and more practically, how far its procedures are relevant to modern-day concerns and easy for ordinary citizens en masse to use.

\subsection{Pro-poor, pro-majority}

Unsurprisingly, poor people are the majority in Afghanistan. Definable poor accounted for 36 percent of the population in 2008 but the figure rises to over half the population when those assessed as "highly susceptible to becoming poor" are included. ${ }^{11}$ As indicated by other AREU research, rural communities have in fact become poorer since 2005. ${ }^{12}$ The same is indicated for urban areas. ${ }^{13}$

Unjust law also disadvantages vulnerable sectors even if some of them may not be poor. In Afghanistan, vulnerable groups are routinely counted as including handicapped persons, landless rural households, nomadic pastoralists (the Kuchi), orphans, returnees and IDPs, sharecroppers, tenants, traditional mortgagors, the urban homeless/shelter insecure, and women. There are also illiterate Afghans who reside in insecure areas of the country and are vulnerable to involuntary land loss.

Poor and vulnerable sectors are together the majority of the population, despite overlaps. Women, of course, are around 50 percent of the population in most provinces. ${ }^{14}$ Landless

\footnotetext{
11 The poor consumed at a level equal to 78 percent of basic consumption needs in the National Risk and Vulnerability Assessment, 2007/08.

12 Paula Kantor and Adam Pain, "Beyond the Market: Can the AREDP Transform Afghanistan's Rural Nonfarm Economy?" (Kabul: AREU, 2011).

13 "Poverty and Food Security in Afghanistan: Analysis based on the National Risk and Vulnerability Assessment of 2007/ 08" (Kabul: The World Bank, February 2012).

14 ICON-Institute, "National Risk and Vulnerability Assessment 2007/ 8: A Profile of Afghanistan" (Kabul: 2009).
}

rural households comprise 30 percent of the rural sector. ${ }^{15}$ Many urban dwellers are not homeowners, are insecurely tenured due to the manner in which their homes have been constructed or face possible forced removal for environmental reasons, ${ }^{16}$ although the extent of tenure insecurity is variable in informal urban settlements. ${ }^{17}$ Returning refugees make up a significant proportion of poor or vulnerable households. Many of the 5.7 million registered returnees have been unable to recover land and houses or never owned a house or farm in the first instance, accordingly returning homeless and landless. ${ }^{18}$ Few have managed to acquire secure rights to houses or farms. ${ }^{19}$ Internally displaced persons (IDPs) presently number 500,000 in only half of the country's districts, meaning the national figure is likely around one million people. ${ }^{20}$ Kuchis, who are around 1.5 million people, include the highest proportion of poor families (54.3 percent) and have significantly less land access than do settled populations (19. 2 percent). ${ }^{21}$

\subsection{Afghanistan as an agrarian economy}

Most Afghans are rural, living in 25,000 to 39,000 settlements, depending on the way they are counted. ${ }^{22}$ The National Risk and Vulnerability

15 This 30.1 percent does not necessarily include tenants and sharecroppers, given the focus of surveys on access to land rather than ownership.

16 The World Bank, "Poverty and Food Security in Afghanistan."

17 For more on differences in tenure security see Tommaso Giovacchini, "Governance and Representation in the Afghan Urban Transition" (Kabul: AREU, 2011).

18 UNHCR, "Annual Statistics," 2009; UNHCR, "Country Profile, Afghanistan," 2009; UNHCR, "Country Operations Profile," 2012.

19 Only 33,774 plots have been distributed to 266,276 applicants (Ministry of Refugees and Repatriation, "Land Allocation Process," December 2011 Data).

20 UNHCR, "Country Operations Profile," 2012.

${ }^{21}$ ICON-Institute, "National Risk and Vulnerability Assessment 2007/ 8."

22 The figures vary depending upon how hamlets are aggregated; 17 percent of hamlets comprise less than 100 people, many of which are sub-parts of clusters. The average settlement size is 481 persons but the median size 
Assessment (NRVA) 2007/08 calculated that 55 percent of all Afghan households are dependent on farming and 68 percent dependent upon livestock, with some overlap. ${ }^{23}$ Land dependence may not be reflected in the contribution agriculture makes to gross domestic product (GDP), especially when opium poppy production is excluded. ${ }^{24}$ However, together with a predicted rise in GDP through mineral extraction (at least 14 new copper, iron ore and other mines are planned for development in the short to medium term), the resource-based composition of the Afghan economy is high, and land access, including to rangelands, is pivotal to socio-economic wellbeing. As poverty is most experienced in rural areas, the overwhelming rural orientation of the 2008 LML and proposed amendments could be considered just.

However, urbanisation has been rapid since the 1990s and is expected to continue to grow, although not to the extent that most Afghans will live in cities and towns. ${ }^{25}$ Nevertheless, the poor could continue to increase as a proportion of the urban population. Present-day realities in developing agrarian economies also suggest that rural and urban land ought to not be separated. It is common for the wealthiest and poorest to have a foot in both town and country. It has been routine for some time for rural Afghan families to dispatch young men to towns to work, and historically large landlords have often been absentee from their farms, conducting off-farm businesses in the urban bases. ${ }^{26}$ Rural urban interlinkages can be anticipated to grow stronger as long as a high proportion of household members are distributed between town and country.

is 309. Central Statistics Organization (CSO), Afghanistan: A Socio-Economic and Demographic Profile: Household Listing - 2003-2005 (2007).

23 The World Bank, Afghanistan in Transition: Looking Beyond 2014, Volume 1: Overview (May 2012).

24 Although the contribution of agriculture to GDP is Iow when compared to opium poppy production, and growth low but steady, its importance for subsistence is undoubted (World Bank, Afghanistan in Transition: Looking Beyond 2014).

25 It is notable, for example, that families remain overwhelmingly rural even in rapidly transforming agrarian economies like India.

26 Cristóbal Kay, "Development Strategies and Rural Development: Exploring Synergies, Eradicating Poverty," The J ournal of Peasant Studies 36, no. 1 (2009): 103-137.
Urban interest in rural land-rights issues, and vice versa, cannot be discounted. What may change is that urban dwellers become more sophisticated and focused in their demands relating to rural rights.

Tenure and governance issues are notoriously complex and contested in expanding cities and towns, especially in peri-urban zones where new housing developments tend to focus. New, creative and forceful strategies tend to be required. ${ }^{27}$ Although historically a rural land law, the LML should be expected to focus some of its attention upon urban property issues. Two key issues in Afghanistan's urban areas concern regularisation of legitimate but untitled occupants of public lands (informal settlements) and legal treatment of rising numbers of privately-built housing estates involving politicians and other notables, made possible by grants of presumed-unowned public land through presidential decree.

\subsection{Fair treatment of majority customary rights in land}

Another broad expectation of sound land law is that it seeks to be plural in its approach to law. This is because both customary law and statutory law usually govern land rights in agrarian societies. Statutory law refers to laws introduced by the state, through decrees issued by leaders or enactments passed by parliaments or other representative bodies. Customary law refers to norms that are community-derived and community-sustained. These are exercised through community-based systems referred to as "customary property regimes." The norms or rules are usually longstanding. Some of these coincide with norms derived from religious law, in this instance Sharia.

Constitutionally, all laws in Afghanistan must conform with Sharia. What Sharia says about land rights is therefore also very important. Defining what land law under Sharia is, however, has

27 Geoffrey Payne, "Land Issues in Rwanda's Post Conflict Law Reform," in Local Case Studies in African Land Law edited by Robert Home (Pretoria, South Africa: Pretoria University Law Press, 2011), 21-38; Leah Onyango and Robert Home, "Land Law, Governance and Rapid Urban Growth: A Case Study of Kisumu, Kenya," in Local Case Studies in African Land Law, 39-58. 
proved to be difficult. This is because decisions that are deemed to be based on Sharia are mainly arrived at by local elders on the basis of customary norms. Judges in courts also do not necessarily have access to extensive religious texts and in practice refer to a single source, more often than not the Civil Code (compiled in the 1970s). This indeed draws upon religious law (from the Hanafi Sunni school) but its 1,000 or so directives relating to land and property are focused upon family property law. The code requires judges to use its provisions in the first instance, referring to older books of Sharia only when the code does not cover the subject. ${ }^{28}$ Local mullahs and judges in formal courts also do not have the benefit of a system of shared legal reporting of decisions, so precedents are not available to build upon.

Much more significant, however, is the fact that the Civil Code encourages rulings to refer to customary norms: "In regard to rights of possession and ownership and other objective rights, the law of the locality shall be applicable where the property is located..." (Article 26). This gives customary tenure significant status. Still, what national laws like the LML say about customary rights is even more important, as state law takes precedence over all other laws (so long as it is consistent with Islamic law).

In practice, there is a high level of integration in statutes of customary, religious and introduced norms. For example, this is seen in what constitutes legal evidence of land ownership. Customary documents are included, presumed to have been written in accordance with Sharia. Land tax receipts of longstanding are also accepted, referring to lands that are most likely to have been acquired through customary norms. When owners filled in forms describing their properties as ordered in the late 1970s, most landholders in rural areas described these lands again (accurately or inaccurately). However, through this information entering official Books of Ownership and Taxation (some 5, 200 of them around the country), this customary ownership gained statutory force. The same may be said for the properties entered into cadastral records from 1964-1978; the maj ority of private properties identified (although only one third

28 Civil Code, Chapter One, Part One, Topic One, Article 1. were covered) referred to lands acquired through local, traditional norms. Many (but by no means all) transfers of residential and farm properties evidenced in court-issued documents (deeds) formalise community-based recognition of rights. In these ways, distinctions between customary and statutory tenure are merged. This is not typical of agrarian states, where distinctions between properties acquired under customary norms and properties established through introduced statutory systems are usually clearer.

\section{A clash of customary and statutory land tenure norms}

This has not meant that customary norms have been entirely embraced by national land law in Afghanistan. On the contrary, many critical features of customary tenure regimes in the country have been excluded. As a consequence, the clash between customary and statutory tenure is ultimately as striking in Afghanistan as in many other agrarian economies.

The reasons are also similar. Past regimes have been careful to pick and choose what they accept as lawful from the customary regime. Globally, a pervasive gap in state law in agrarian countries concerns treatment of off-farm lands and how far customary rights to such lands are acknowledged as existing in the state's laws, and therefore how far those rights will be protected.

This is precisely the case in Afghanistan. Historically, the LML has focused upon visibly utilised lands as potential real property; that is, houses and farmlands. The reality is that cities and towns absorb one percent of the total land area of Afghanistan while permanent farms encompass not more than 12 percent. So who owns the remaining 87 percent of the country's land? Broadly, in a word, the state.

While for some parts of the country this was made law 100 years ago by the rapacious "Iron Amir" Abdur Rahman, ${ }^{29}$ it took longer for the 20th century Afghan state to take legal possession of off-farm lands. It variously categorises these

29 Particularly the case for Hazaraj at; see Alden Wily, "Land Rights in Crisis" for details. 
as arid, virgin or rangelands, and presumed all rights to determine who used these and how. This reached a peak with the drafting of the early versions of the LML in the 1960s (much assisted by early USAID projects, which again are assisting the Afghan government to amend its laws, toward a more investor-friendly environment). ${ }^{30}$ The position since has been that individuals, groups and clans may access this state property. Or, with the agreement of the head of state, they may also purchase it. The President may also allocate these lands through lease.

The problem is that these lands are, as often as not, by customary norms the traditional collective property of a community. Space does not allow for a recount of the many conflicts between communities and among ethnicities that this statutory dispossession has triggered, especially over the last half century. ${ }^{31}$ The denial of community-based rights has also quite predictably engendered classical land-abusing symptoms of open access in regard of these offfarm resources. After all, in times of a limited presence of agricultural officials and rule of law, such as experienced since 1978, government lands are treated as available assets even more so than in more regulated times.

Closely linked to state law treatment of offfarm land rights is weak provision for real property to be owned in common. While Sharia acknowledges that land may be owned collectively, Afghanistan's national land laws have not taken this up, other than in limited versions, such as will be discussed later in this paper.

\section{Minimal support for community-based land governance}

There are other ways in which existing and past versions of the LML have fallen short on matters of pressing interest to the rights of most citizens. The LML, like the Civil Code, is silent on the status of land and property decisions arrived

\footnotetext{
30 This history of the LML and related laws is found in Alden Wily, "Land Rights in Crisis" and "Looking for Peace on the Pastures: Rural Land Relations in Afghanistan" (Kabul: AREU, 2004).

31 This matter will be covered in a further AREU paper.
}

at through community-based mechanisms. Continuing determination to formalise all rights to land in a single, comprehensive and surveybased register makes this problematic, for there is no evidence that the state can achieve this without the full participation of the population. Fielding high-level government teams to identify, adjudicate, map and record each and every land parcel is prohibitively costly in time and expense. Afghanistan has direct experience of this in its efforts from 1964 to do so, backed by no fewer than 600 US-trained staff and as many vehicles. Even then it was unable to cover more than one third of the country within the decade, by which time formal mapping intentions had been abandoned. ${ }^{32}$ Costs are not the only issue in such titling schemes. The creation of land administration procedures rooted in the community open the way for a great deal more accessibility for the maj ority, and accountability to them as landholders. Remote, costly systems, within which records disappear to central archives, are increasingly understood as a form of governance dispossession in itself, inimical to inclusive democratic process. ${ }^{33}$

This is relevant to both urban and rural domains. A great deal of community mobilisation has been undertaken in the last decade in Afghanistan, which provides the building blocks toward a rational expectation for community-based land administration. Representative councils at village and neighbourhood levels are cornerstones, with strong potential to be accountable to community members. Local land committees could evolve on an incremental basis, slowly accruing functions and powers in line with capacity development and rigour in accountability. Their grassroots location alone and the extreme reduction in costs that this allows offers an opportunity for the estimated 80 percent or so of households who have no formal documentation to acquire or prove their rights, and thus no protection of those rights by the law. If experience in other countries is to be observed, it is quite possible to devise a simple but accountable system for mass uptake by local communities, subject to external inspection by state-appointed officials,

\footnotetext{
32 Yasin Safar, "Land Tenure Administration and Property Rights Management in Afghanistan" (May 2012).

33 Issues of community-based land administration regimes will be covered in a following paper.
} 
that can deliver fully workable, communityendorsed recordation of land rights in formats laid down by the advising state authority. Crucially, such community-based regimes make it just as easy for changes of ownership to be cheaply and promptly added to those records, difficulties around which routinely cause more centralised and costly systems (for the landholder especially) to stumble. At the moment, the poor, the vulnerable and the uneducated-in short, the majority of Afghanistan's populationhave almost zero access to the systems that deliver what the law describes as "legally valid documents of ownership." The following review of proposed amendments to the LML looks closely at how far they are designed to enhance popular access.

\subsection{National land policy as a benchmark}

There are more particular aspects that need to be assessed, such as relating to the proposed treatment of the rights of women and vulnerable sectors, the extent to which compulsory acquisition by the state is made more just, and the attention the law gives to tackling well-known malfeasance in the administrative systems and rampant land grabbing by elites with connections. An assessment must also examine the balance offered by the law between promotion of commercial land use and protection of majority subsistence and housing rights. Topically, how does the proposed amended law deal with the equally well-known fact that millions of people now occupy lands and houses in towns and cities in ways not recognised as legal? Are they all to be evicted? Or does the law propose to regularise their occupation? What are the strategies for this?

To this end, an enormously helpful fact is that many of these issues have already been thought through by the Afghan government and have been delivered in a digestible document, the National Land Policy (NLP) of 2007. Although developed without formal public consultation, which international practice now demands, the NLP evolved through substantial inter-ministerial consultation over two years. Important inputs were provided by practical projects tackling land tenure and administration issues in different parts of the country. ${ }^{34}$

The provisions of the NLP are largely (if often mildly) consistent with international best practices in land governance, laying out broad objectives, principles and some 40 other related policies clustered into 20 policy statements. It is therefore practical to use it as a basis to assess the social soundness of the proposed land law changes.

\section{Proposed Amendments to the Land Law}

\subsection{Many changes but not much change}

Some disappointments are immediate, for even a cursory read of the amendments proposed by 31 December 2011 suggest that there is no desire to broaden the scope of the LML or transform it into a modern, basic land law. This remains a land administration law (termed "Iand management" in the English translation).

More startling, there is little to no sign that the drafters have taken the directives of the new National Land Policy into account. Indeed, suspicion must be raised that they have not themselves accessed and absorbed the policy. There is certainly no sign of this in the retention of old objectives guiding the law (in Article 2, except one omission discussed below). The policy directives show little evidence of reshaping substantive provisions in the law.

Table 1 provides an outline of the proposed structure of the law. One new chapter addressing land grabbing is introduced in addition to those already in place in the 2008 law.

\footnotetext{
34 This included, for example, the work of the USAIDfunded project Land Titling for Economic Restructuring of Afghanistan (LTERA) (2006-09), the DFID/ ADB-funded Rural Land Administration Project (RLAP) (2006-08) and the FAOfunded pilot project under its Sustainable Agriculture Proj ect in Eastern Hazarajat (SALEH), which developed and tested an integrated approach to community-based pasture tenure and governance during 2006-08, now applied by several lead field INGOs.
} 
Table 1: Main Subjects of the Land Management Law (2008) and the New Draft (2012)

\begin{tabular}{|c|c|}
\hline $\begin{array}{l}\text { Chapter } \\
\text { (Articles numbered per new } \\
\text { version) }\end{array}$ & Main Subjects of the Chapter \\
\hline $\begin{array}{l}\text { Chapter One: Main } \\
\text { Provisions } \\
\text { Articles } 1-4 \\
24 \text { new sub-articles }\end{array}$ & $\begin{array}{l}\text { - Objectives of the law ( } 1 \text { omission) } \\
\text { - } 46 \text { Definitions ( } 24 \text { new) } \\
\text { - Authority of the Afghanistan Land Authority (ARAZI) over land affairs }\end{array}$ \\
\hline $\begin{array}{l}\text { Chapter Two: Legally Valid } \\
\text { Documents Related to Land } \\
\text { Ownership } \\
\text { Articles } 5-12 \\
\text { No new articles }\end{array}$ & $\begin{array}{l}\text { - Distinction between official and unofficial valid documents } \\
\text { - Description of state decrees, tax receipts, water rights documents, and customary } \\
\text { - Conditions affecting official documents } \\
\text { - Conversion of documents into deeds } \\
\text { - Immovable non-land equipment } \\
\text { - Lack of legally valid documents } \\
\text { - Surplus land belongs to the government } \\
\text { - Provision of documents to those distributed land by the government }\end{array}$ \\
\hline $\begin{array}{l}\text { Chapter Three: Land } \\
\text { Settlement } \\
\text { Articles } 13-27 \\
4 \text { new articles }\end{array}$ & $\begin{array}{l}\text { - Land clearance procedure (survey, mapping, identification and assessment of } \\
\text { documents, referral of disputes that the Clearance Commission cannot resolve to } \\
\text { other bodies, registration, preparing of deeds, restitution of wrongfully distributed } \\
\text { lands to original owners) } \\
\text { - Role of the cadastral team } \\
\text { - Cooperation of land owners } \\
\text { - Central Commission of Land Authority and Provincial Commissions } \\
\text { - Expropriation of private land } \\
\text { - How registration of collectively owned lands with documents of co-owners will be } \\
\text { - } \text { distinctly registered } \\
\text { Replacement of destroyed documents }\end{array}$ \\
\hline $\begin{array}{l}\text { Chapter Four: Restitution } \\
\text { of Grasped Lands to Their } \\
\text { Owners } \\
\text { Articles } 28-32 \\
1 \text { new article }\end{array}$ & $\begin{array}{l}\text { - } 7 \text { Land taken without payment of compensation since } 27 \text { April } 1978 \text { (7 Saur 1357) } \\
\text { - How land and payments made since original taking will be recovered } \\
\text { - Particular attention to restitution of government lands }\end{array}$ \\
\hline $\begin{array}{l}\text { Chapter Five: Eligibility } \\
\text { Articles } 33-36 \\
2 \text { new articles }\end{array}$ & $\begin{array}{l}\text { - Definition and ranking of who is eligible for state land allocations } \\
\text { - Return of unused land to government }\end{array}$ \\
\hline $\begin{array}{l}\text { Chapter Six: Land } \\
\text { Distribution } \\
\text { Articles } 37-47 \\
2 \text { new articles }\end{array}$ & $\begin{array}{l}\text { - Who is responsible for this } \\
\text { - How the price of lands shall be determined } \\
\text { - } \text { Prior survey and planning required } \\
\text { - Land Distribution Delegation } \\
\text { - Allocation by drawing lots } \\
\text { - Sale and transfer of state lands, and conditions } \\
\text { - How applications are to be made }\end{array}$ \\
\hline
\end{tabular}




\begin{tabular}{|c|c|}
\hline $\begin{array}{l}\text { Chapter Seven: Land } \\
\text { Transfer and Alteration } \\
\text { Articles } 48-56 \\
\text { No new articles }\end{array}$ & $\begin{array}{l}\text { - } \text { Free registration of private sector transactions } \\
\text { - Legal only via ARAZI and courts } \\
\text { - Alteration is size or tenure to be subject to survey } \\
\text { - Transfer of government land to government entities } \\
\text { - Exchange of land } \\
\text { - Transfer of lands based on Sharia documents } \\
\text { - Return of unused agricultural land distributed to cooperatives since April } 1978\end{array}$ \\
\hline $\begin{array}{l}\text { Chapter Eight: Lease of Land } \\
\text { Articles } 57-80 \\
4 \text { new articles }\end{array}$ & $\begin{array}{l}\text { - How leases are issued } \\
\text { - Size of lands that may be leased for different purposes } \\
\text { - } \text { Availability of virgin and arid lands to investors } \\
\text { - Rental on leases } \\
\text { - Termination of leases } \\
\text { - Obligation to report natural plagues on leased lands } \\
\text { - Right to sub-lease to third parties (new article) } \\
\text { - Leasing with the private sector permitted (new article) } \\
\text { - Leases not permitted in specified areas (e.g. protected areas, pasture and public } \\
\text { lands) (new article) } \\
\text { - Establishment of a Land Leasing Auction Commission (new article) }\end{array}$ \\
\hline $\begin{array}{l}\text { Chapter Nine: Mar' aa and } \\
\text { Endowed Land } \\
\text { Articles } 81-86 \\
3 \text { new articles }\end{array}$ & $\begin{array}{l}\text { - Mar'aa defined as virgin or arid lands not owned privately or by government } \\
\text { - Rights to trees and existing cultivation on endowed land (new article) } \\
\text { - Demolition of trees planted and structures built on endowed lands (new article) }\end{array}$ \\
\hline $\begin{array}{l}\text { Chapter Ten: Land Grabbing } \\
\text { Articles } 87-94 \\
\text { New chapter: } 8 \text { new articles }\end{array}$ & $\begin{array}{l}\text { - Identification of land grabbers } \\
\text { - Grabbing of private lands } \\
\text { - Zero right of compensation for grabbers } \\
\text { - Actions required of entities in respect of state lands } \\
\text { - Prevention of land grabbing } \\
\text { - Referral of cases to judicial bodies } \\
\text { - (All new articles) }\end{array}$ \\
\hline $\begin{array}{l}\text { Chapter Eleven: Penalty } \\
\text { Provisions } \\
\text { Articles } 95-99 \\
2 \text { new articles }\end{array}$ & $\begin{array}{l}\text { - Penalties for land grabbers } \\
\text { - Destruction of land structures, irrigation canals, and other immovable property } \\
\text { - } \text { Compulsory registration of changes in holding, transfers, etc. } \\
\text { - Revocation of distributed land that is not developed }\end{array}$ \\
\hline $\begin{array}{l}\text { Chapter Twelve: Final } \\
\text { Provisions } \\
\text { Article } 100-111 \\
5 \text { new articles }\end{array}$ & $\begin{array}{l}\text { - Rectification of mistaken information relating to holdings } \\
\text { - Prohibited non-agricultural activities on agricultural land } \\
\text { - Use of Iands for intended purpose (new article) } \\
\text { - Obligations of ARAZI and Municipalities re registration (new article) } \\
\text { - Obligation to rehouse those whose land expropriated if compensation not paid } \\
\text { (new article) } \\
\text { - Consolidation of small plots of arid and virgin land with neighbouring landowner } \\
\text { for payment } \\
\text { - Authority of President and responsibility of Governors (new article) } \\
\text { - Responsibility of ARAZI and Municipalities }\end{array}$ \\
\hline
\end{tabular}


So what actually will change in the LML should the proposals be adopted? Changes include the removal of 12 articles from the 2008 law, the addition of 55 new articles, and 100 alterations to existing text. However, few alter the effect of the 2008 law. The removal of standing articles is mainly editorial. Key substantive omissions concern how land is leased to investors, the major new subject introduced into the law in 2008. This includes removal of the new objective in 2008 to "Create favourable opportunities for active and broad-based participation of the private sector in land affairs" (Article 2[8] of the 2008 law).

Not all omissions are positive. One that could negatively affect poor people concerns tax receipts as evidence of ownership (Article 27). While many warlords collect taxes, official payment of land tax has been largely suspended since 1978. As such, holding land tax receipts is meaningless. However, many poor rural families only have tax receipts in their possession as evidence of ownership. Some of these date back to the 1930s. Removal of the long-standing provision that such people are due acknowledgement of ownership could be detrimental for this sector.

Many additions to the law are also for editorial clarity only. Twenty-four of the fifty-five new sub-articles introduce meanings of terms used in the law. ${ }^{35}$ Some new definitions are not delivered consistently in the main text of the law. Others hint at some demise in the legal standing of rights that lack legal documentation (Article 3[2]). "Landowner" now means a person who owns the land on the basis of legally valid documents, while a "land possessor" is defined as a person who holds the land but does not have legally valid documents. The distinction becomes awkward when "owning possession" is then defined (Article 3[27]).

\footnotetext{
35 These terms are now given definition: land, nonagricultural land, general mar'aa land, special mar' aa land, commonly held land, owning possession, land settlement, area evaluation form, re-registration form, settlement delegation opinion, tax, temporary tax, kishtmandee (an old land duty), auhda-e omree (an old tax), lease, lessor, lessee, rental amount, auction, land grabbing, land grabber, person harmed by grabbing, restitution, person, Afghanistan Land Authority. Still missing definitions include ezafa jiribi (surplus land) and temporary document (provisional title).
}

The proposed renaming of "government lands" as "state lands" is a useful reminder that government only owns property on behalf of the nation. However, this is purposeless because parts of the law refer still to "government land." The distinction between state/government and public lands is important and a traditional component in this law, although seemingly abandoned in President Karzai's Decree 83 of 2003.

\subsection{Collective property is still not provided for}

More serious is the continued absence of workable proposals for collective property or what the NLP refers to as "community land." An attempt in this direction is made. "Commonly held land" is introduced under definitions for the first time (Article 3[17]). In the English translation by the drafters, this is fairly described as "the land that is shared between two or more persons in a manner that each partner has partnership in each portion of the commonly held land accordingly."

However, the draft lets itself down in two ways. Firstly, it fails to follow through with a construct for collective ownership that would apply to community-owned pastures, the major collectively owned resource. Instead, Article 25 refers to several persons combining their individual properties for a special purpose, such as for mechanised farming. Even on this count, the provision for joint ownership is too narrowly built on a rural farm initiative, not easily applicable to cases where several persons co-own a building.

The process for defining rights within this estate shows it is not common property in the true sense of the word. For taxation purposes, for example, Articles 25-26 of Chapter Three explain how members must describe their own discrete portion of the combined estate on forms. This is irrelevant to cases where the land itself and rights associated with it is held in undivided shares. This is normal for naturally collective properties such as forests, swamps or pastures, which are not rationally or easily subdivided into individual parcels. 


\section{Collective use rights, not ownership rights, are provided for}

Allocation of a collective use right is provided for in the law. This is through a newly introduced class to be known as "Special Mar' aa Land." This is a sub-category of public land (i.e. unowned and unownable land), which is land designated for the use of an adjacent community (Article $3[33])$.

Strictly speaking, provision for this is far from new; only the terminology is new. Even in 1965 and in the Law of Pasture Lands $1970^{36}$ a community could secure exclusive user rights to an immediately local area of rangeland. This was also retained in the 2000 and 2008 versions of the LML. The Taliban version of the LML (2000) famously defines such lands as extending as far as the human voice may be heard from the edge of the village. Unfortunately, Chapter Nine on Mar'aa and Endowed Land fails to develop a simple procedure for identifying such lands, not even mentioning the Special Mar'aa it defined at the beginning of the law.

Should Special Mar'aa be properly developed in the new version of the LML, this will indeed meet some demands of local communities concerning their rights to immediately adjacent public lands. It could be argued (and will be argued by leading officials loathe to surrender real rights to ordinary citizens) that communities should be satisfied with use rights. This remains a far cry from the more potent demand for not just allocation of priority and even exclusive use rights to such lands, but for these communal assets to be recognised as owned by those communities. In light of the fact that inadequacies in recognising local rights to off-farm lands has created so much dispute and even armed conflict, this is a serious omission. ${ }^{37}$

\footnotetext{
36 Official Gazette no. 180.

37 This matter has been thoroughly covered in Alden Wily, "Looking for Peace on the Pastures"; Lenard Milich, "An Analysis and Evaluation of the Behsud Conflicts, 20052008 (1384-1387) and a Blueprint to Avoid Further Clashes in 2009 (1388) and Beyond" (Kabul: AREU, 2009); and Liz Alden Wily, "Recommended Strategy for Conflict Resolution of Competing High Pasture Claims of Settled and Nomadic Communities in Afghanistan" (UNEP, 2009). Additionally, both the MAIL/ADB and MAIL/FAO projects addressing pasture rights issues developed consistent methodologies for
}

The distinction is not a technicality for as long as such lands remain classified as unownable public land (although able to be allocated for use by a specific village), communities are routinely prone to losing these lands and the immense value they garner through state reallocation to preferred rangeland users, or for other purposes altogether (e.g. mining, private livestock enterprises or land settlements).

Communities have suffered all these fates. For example, historical allocations of high pastures in Hazarajat to Kuchis, either as individual families or as clans, has periodically reached war footing in some areas and continues to do so seasonally in Behsud and Nawor Districts.

In any event, the definition of Special Mar'aa appears to exclude a good number of pastures by describing these lands as "located and linked with a respective village" (Article 3[13]). This usually refers to small pastures that are immediately adjacent to the settlement, but fails to cover higher altitude or remoter pastures over which settled communities have historically enjoyed private, community-based rights. These may be several hours or several days walk from the village. Historically, in both the north and in the central highlands, high altitude pastures have a long history as the claimed communal property of particular agropastoral communities.

This is not to say that outsiders were prevented access; on the contrary, these owners (or at least their leaders) could make substantial incomes in the form of "sweets and sheep" from charging outsiders for seasonal grazing access. From the 1890s, various kings and then presidents and more recently their governors have seen fit to deny local tenure and reallocate the better of these alpine pastures to mainly Kuchis. It would be a mistake, however, to presume that local claims simply disappeared. Instead, these routinely went underground as bitter, festering grievances that resurfaced with a vengeance during the conflict years in widespread recapture of pasture rights. Kuchis have been at the receiving end of this resurgence in common property claims, denied re-entry in many cases.

identifying, resolving and recording disputed rights, which one would now expect to be given legal force on this subject. 
The ambivalence of the LML toward public lands has also not been helpful. The law traditionally permits these public lands to nevertheless be effectively sold or allocated in perpetuity to particular persons. Uncertainty as to pastureland tenure is then multiplied by unsatisfactory distinctions among lands deemed to be arid, virgin or rangeland, each of which may be allocated by the state in different ways. In practice, a good deal of rangeland is at the same time either arid (waterless for most of the year) or virgin (never been cultivated).

\subsection{Sustained reliance on documentation discriminates against the majority}

The definition of legally valid documents for the purpose of proving land ownership has been a central component of land law in Afghanistan and a core subject of the LML in particular. This continues to be covered in Chapter Two: Legally Valid Documents Relating to Land Ownership. What constitutes a legally valid document has been re-engineered slightly but neither the menu of available routes to lawful occupancy nor remedy against falsification of documents is much altered in the proposed amendments.

New classifications (Article 5[1] and 8[1]) of valid documents are deceptive. The change is that "legally valid documents" are subdivided into official and unofficial documents, a naming change more than anything else. Customary documents now fall into the latter. ${ }^{38}$

The definition of what constitutes a customary document remains unchanged (Articles 5[1] and 5[5]). Customary documents must have been prepared before 6 August 1975 and the buyer must have completed a form describing his land before 1978. Where these forms were not distributed, or the registration book of ownership destroyed, the possession of the holder may be confirmed by neighbouring farmers, partners and residents of the community where the plot is located. These provisions were already in place in 1978 and the process of conversion

\footnotetext{
38 The former is to include court-issued documents and ownership through state decrees (sadarat), and other official land documents including land tax documents, water rights documents, cadastral documents and ezharnamas (submitted forms describing one's holding) issued from 19751978 (SY 1354-1357).
}

into a statutory entitlement was available from the 1960s, as based on formal survey and adjudication. As noted earlier, this process was in fact halted, mapping diminished and the results in the cadastral registers referred to as only probable ownership, in light of the lack of final verification. For even longer, customary owners have also been able to convert documents into Sharia entitlements through the courts, a procedure that is prohibitively expensive in fees (and especially bribes) and only used by elites.

\section{Documentless customary owners still remain technically landless}

Article 8(1) also deals directly with cases where a possessor of land is not in possession of a legally valid document and where the land is also not registered in the principal book of ownership held by the government. If there are signs of agricultural development on the land and the neighbours confirm that the possessor has been there since 1965 (15 years before 6 J adi 1358) and the land is not within a government project, then the possessor may claim up to 50 jeribs ( 10 ha) of the parcel as his property.

This is not a new opportunity. The proposed change refers only to the size of areas eligible for such acknowledgement as property. In the LML 2000, 10 jeribs (2 ha) was stipulated as claimable as owned land under this process of conversion. In the LML 2008, this was raised ten-fold to 100 jeribs. The claimant, following identification of the area, could buy the excess in instalments over a period of five years. The permissible registrable area is now halved to 50 jeribs (10 ha).

Several problems arise in these provisions for regularisation of undocumented possession:

1) The conditions upon which claims can be made are not appropriate to households that have acquired lands since 1978/ 79 and who may have no customary basis to their claims. This includes several million urban occupants since the early civil war era, including more recent returnees occupying public lands. It also affects those who never had documents, never had farmland but owned shares with other community members in rangelands, and those who were 
not educated or aware enough to have their lands entered into Books of Ownership and Taxation in the late 1970s.

2) As observed earlier, the Taliban avoided specifying that a person had to have owned the land since 1973 as was introduced into the law in 2008. The proposed changes are yet more constraining, making it possible to claim such lands only if neighbours confirm these lands to have been owned 15 years before 1979; i.e. as long back as 1964.

3) Due to the requirement that land be visibly under cultivation, these provisions could also negate the rights of people who may be unable to farm because they can no longer access their lands; for example, due to commander control or ethnic tensions. This is the case for many families of Pashtun origin who colonised parts of the north up to 100 years ago but who fled during the Russian and muj ahiddin periods as indigenous Uzbek, Turkmen and Hazara communities rebelled against their occupation and dominance, including in terms of controlling rights to pastures, and who have not been easily able to return to their homes since.

4) The procedure for identifying owners is not such that it could ensure that those most likely to possess small lands with no evidential documentation-i.e. the land poor-are properly captured in the process.

5) There is a troubling caveat (Article 8[2]) that government documents nullifying possession may be issued through a process that does not involve those affected at all. This can occur when the President allocates presumed public or state lands to others. Issue of leases, for example (see Article 69), by law only necessitate an inspection procedure that is geared to identifying the type of land (arid, virgin or rangeland) and not to discovering if the land is rightly presumed to be applicable unowned land. This relates to the problem of Afghan land law that such lands are generically considered ownerless. There is plenty of scope in such provisions for injustice.

6) The legal status of undocumented land ahead of adjudication (tasfeya; "clearance" or "settlement") of rights is unclear. In a modern land law, explicit protection of unrecorded rights pending adjudication is expected.

The result of all the above must be a presumption that people who own lands or co-share pasture lands customarily but without documentation are technically landless in the eyes of the law. New provisions and adjustments of language in the LML have not altered the bottom line: that protection of rights depends in practice upon the owner holding a deed that has been issued by the courts. On this basis alone, it may be concluded that the majority of Afghans would still not be offered basic land rights protection. Any lands they own in common are especially vulnerable to state-endorsed seizure and they are also vulnerable to an inability to defend their rights in the courts.

\section{The law is ambivalent as to compulsion to formalise interests}

While the registration of rights has been compulsory in previous versions of the LML, this is not explicitly the case in the 2008 version or in current proposed amendments.

Failure to inform ARAZI of changes to a landholding is made an imprisonable offence (Article 98). A new provision also makes it compulsory for a municipality or expropriating authority of private lands to register changes in the local ARAZI office (Article 103). Although this compulsion is not otherwise stated, encouragement toward registration (in the sense of securing court-issued ownership documents) is implicitly an objective of the law (Article 6). The absence of explicit compulsion does not remove practical constraints to mass uptake of this objective, which requires funds, guidance and support that most of the population simply do not have. This compounds injustice with discrimination.

\section{Provisional entitlement is weakly provided}

Forms of provisional entitlement are mentioned but restricted to the issue of temporary distribution documents to those who are allocated parcels in settlement schemes (Article 11). This is relevant only to a small proportion 
of the population. While several projects have developed other ways to record rights, the legal drafters show no signs of taking this into account. For example, a USAID-funded land project is helping occupants in two informal settlements in Jalalabad to secure provisional title. A UN-Habitat project has developed a process that issues a safaey (a sanitation tax notebook) to informal settlers in Kabul and Kandahar; this recognizes their occupation (and that they have paid tax). A disconnect seems to exist between the law saying property tax receipts are acceptable as evidence of ownership but, by omission, the sanitation tax is not. A 2006 policy designed to regularise the occupation of millions of informal settlers in Kabul and other cities and towns does not appear to have been taken on board, nor do the directives of the NLP on this subject.

\subsection{The unchanged clarification procedure is not applicable at scale}

Chapter Three on land settlement covers what in other laws might be known as "adjudication, survey and registration." This procedure of tasfeya is described in English as "clearance" and "settlement." But naming is not the issue; the procedure is.

1) Description of the procedure is patchy. The survey tasks of the cadastre team are identified (Article 16) but the tasks related to discovery, identification and adjudication of rights are not described.

2) The process fails to institute local participation in the identification of rights. There is no legal assurance that those whose individual, family or collective properties within the area being cleared have a legal right to present their claims or to participate in any active way in the procedure. Instead, the law only orders them to cooperate (Article 18). While in practice local elders at least are consulted, the law does not make this obligatory. Changes to the law that make private housing schemes legal on clearly laid out conditions, including an obligation to include low-cost housing along with public service areas and facilities
3) There is nothing in the procedure described that suggests clearance is designed for mass application (Article 20). Instead, this is to be conducted by a large, high-level team (that will require transport and living costs and all members of which would have other matters to attend to). It must be concluded that "clearance" is geared to specific oneoff occasions, such as where an individual applies for a large area of government or public land, or where wealthy people want to secure formal certification for their holdings.

4) The proposed amendments make no change at all to the hefty role played by the judiciary in determining title. The Supreme Court provides a member of the Clearance Commission. The record ("Clearance Opinion") is to be approved by the Supreme Court. This suggests the government has not made progress is persuading the judiciary that their neutrality is jeopardised when they decide disputes about the very properties they have helped adjudicate.

5) Clearance is structured entirely as if it still only applies to rural lands.

6) The casual addition of restitution of lands distributed against Sharia into the process of clearance is alarming (Article 15). Taking peoples' lands is a serious proposition, and it is preferable that the law deals with restitution of lands to rightful owners through a quite different procedure than adjudication.

7) Distribution that is "against Sharia" requires a more specific definition of what this means in defining rightful property.

Again, the end result of the unreformed LML is that the majority are caught between a rock and a hard place. On the one hand the law proposes no democratic and inclusive procedure through which certification of rights may be obtained en masse. On the other hand, the law does not endow locally accepted tenure with interim protection until they have the immense financial and other means to secure legal entitlement. 


\subsection{Expropriation procedure shows no sign of reform}

Compulsory acquisition is covered in Articles 21-22 of Chapter Three. The right to buy private land for a public purpose is a normal state right. Here, in the LML, only one new article is proposed. This makes it lawful for an expropriating authority to rehouse an expropriated owner rather than paying the price of the land (Article 104). It would be fairer for the law to enable the affected person to decide if they wish to be rehoused or to receive the full cash value of compensation in lieu. As an afterthought (it seems), additions are made in the last chapter on final provisions. New Article 103 requires authorities to formalise changes of ownership resulting from expropriation. Article 104 repeats the above provision that authorities may compensate those whose lands are taken for a public purpose through rehousing.

These are fragmentary additions to a procedure of immense importance to ordinary Afghans, particularly in the face of rapidly expanding urban areas and anticipated evictions due to the allocation of rural lands for mining, gas and oil purposes, as well as the smaller scale leasing of lands to investors. There is a host of best practice that ought to be considered. Basic requirements like a tightening of the definition of what constitutes public purpose is not provided. Structurally, the provisions are located strangely in the chapter on land allocation and registration. If the subject is going to be retained in the $L M L$, it needs a separate chapter and much more thoughtful treatment. In light of the fact that the LML is visibly not intended to become a single, comprehensive new land law, it seem sensible to leave the development of this important subject to the revision of the Land Acquisition Law (also known as the Land Expropriation Law). This is also under amendment.

\section{No limitation upon arbitrary evictions}

However, an important related gap must be filled in this law: a limitation of arbitrary eviction, whether through compulsory acquisition or in other circumstances, and whether conducted by the state or officials or by private persons. There are at least three points in the law where this should have been covered: where the state is restoring properties to original owners and which may affect lawful occupants; when the state reallocates land it presumes to be unowned public land to investors but finds occupants; and where it wishes to remove people from unplanned or environmentally dangerous areas. A general chapter is needed to guide and prevent human rights abuses in the course of implementing the law in these matters.

\subsection{Restitution is not discernibly pro- poor or necessarily just}

Restitution is covered in Chapter Four (Articles 28-32) with minor changes on provisions from the 2000 and 2008 versions of the LML. ${ }^{39}$ The chapter refers to lands or houses that were redistributed in accordance with land policies from 1978 and did not require compensation to be paid to the owner. This is further complicated in cases where previous regimes have allocated empty buildings, apartments or parcels. There are cases of private houses or farms having been wrongfully occupied by individuals and for which they have since secured legally valid documentation. As the poor performance of the Special Land Disputes Court (2003-2005) indicates, the resolution of restitution cases is extremely difficult. ${ }^{40}$ Many who fled conflict during 1978-2001 are still unable to regain their properties. ${ }^{41}$ Inconsistency in rulings and alleged demands for bribes delay restitution. ${ }^{42}$ The revision of the LML provides an excellent opportunity to rethink how restitution can be fairly and promptly pursued and to lay down a new legal platform for this, since it is currently missing.

\footnotetext{
39 One new paragraph is proposed in this chapter (new Article 30[4]) but is very similar to the existing Article 29 (new Article 28).

40 The World Bank, "What are the Sources of Conflict in Urban Land Tenure?" Kabul Urban Policy Notes, Series No. 4 (2005).

41 Over 52 percent of land cases involved this matter in 2011 (Norwegian Refugee Council [NRC], 2011 statistics on property claims).

42 More information on the returnee and IDP restitution issue may be found in Sheila Reed and Conor Foley, "Land and Property: Challenges and Opportunities for Returnees and Internally Displaced People in Afghanistan" (NRC, 2009) and Ingrid Macdonald, "Landlessness and Insecurity: Obstacles to Reintegration in Afghanistan" (Middle East Institute, 2001).
} 
Sitting tenants are also affected by restitution claims. The 2000, 2008 and now the proposed LML perceive all distribution of lands from 1979 as wrongful. However, landless tenants, sharecroppers and workers were among beneficiaries of redistributive reforms and it would be unfortunate to compound one inj ustice by visiting a further inj ustice upon these poorer groups, who may not have had the means until the present to pay the state for those small land grants. As observed above, sudden eviction and without provision for resettlement is not strictly outlawed. A vague reference to Sharia in Article 32 is an inadequate protection. Nor can restitution intentions be fairly delivered without thorough, localised investigation of occupancy on the ground. There is nothing in the revised LML proposals that require this to be carried out.

\subsection{State commitment to distributing lands to the poor is further diluted}

It was noted earlier that a pro-poor agenda increasingly characterised Afghanistan's land law during the 1970s, and especially from 1979, but has diminished since the 1990s. It is not just redistribution that has given way but the longstanding obligation that the state has laid upon itself to allocate lands from its own immense estate to those seeking land to construct houses or to farm. Provisions for such allocations remain in the law but have been revised (Articles 33-38). Three observations need to be made on the proposed paradigms: firstly, allocation of lands to needy persons is not longer an obligation; secondly, the definition of eligible recipients has been broadened to include any person in the district (Article 35[2]), which could include large landowners; ${ }^{43}$ and thirdly, the proposed amendments are silent on the need to include urban dwellers in need of housing in its purview. While it could be argued that the Municipalities Law is the place for such developments, the commitment to the provision of low-cost public housing or plots is overdue.

\footnotetext{
43 It is worth noting that the Taliban LML of 2000 made as third priority a farmer with a small landholding or a retired civil servant with a small or no landholding who has provided 25 years of service and is given land in lieu of a pension. The fourth priority was a "hapless nomad" (Article 39, Official Gazette 795, 2000 [SY 1421]).
}

Proposed new articles require distributions to be undertaken only after a comprehensive plan of action has been developed and approved by the president (Article 37[5]). Article 42 creates a Land Distribution Delegation, comprised of ARAZI, the Afghanistan Geodesy and Cartography Head Office (AGCHO) and the Ministry of Agriculture, Irrigation and Livestock (MAIL) extension officers, with the opportunity to appoint others. This looks good but practice so far suggests a much more rigorous set of conditions need embedding in the law because many settlers are offered plots in remote and waterless areas or offered lands that local communities al ready claim as their own. ${ }^{44}$

A fourth point needs noting: the distribution of public land to needy individuals is premised on the requirement that they pay for the land, in instalments if necessary. Failure to make payments results in eviction (Article 99 under Chapter Eleven on Penalties). This seems harsh in light of the poverty of many landless persons who are supposed to be given land precisely to alleviate their poverty and who are not given tools and seeds to begin farming. As recorded earlier, few IDPs and returnees have been able to pay for their plots.

\subsection{State powers over land are enhanced}

Provisions for more general allocations of state and public lands are provided in Articles 45-47, with no changes from the existing law (in place from 2000 onwards). A pre-sale assessment is to be made, geared to the potential of the land while taking note of the rights of neighbouring landowners when cultivating or constructing buildings (Article 46[2]). There is no procedure for discovering if the land is unowned prior to allocation or an obligation to identify use rights to the land. There is no procedure for involving local populations at all. Accordingly, there is also no provision for affected persons to appeal. It is as if the Afghan population is invisible to the state. If anything, presidential powers to sell any virgin or arid land are reemphasised. The state cannot sell or distribute government property, land under government projects or master plans, forests, pastures,

44 The Land Allocation Process as reported upon in December 2011 by the Ministry of Refugees and Repatriation. 
mines or historical monuments (Article 46[1]). This is discussed further below.

The transfer of private lands is covered under Chapter Seven (Articles 48-56), with no changes. ${ }^{45}$

\subsection{Lessees and investors are better supported than ordinary citizens}

Proposed amendments to the LML alter the provisions on leasing, introduced into the law as recently as 2008 . Five articles on this subj ect are omitted and four new articles added. The omissions are mainly editorial. The only real change concerns the size of lands that may be leased, making reductions on the leasingenthusiastic 2008 law (Article 63[1]). Purposes of leases remain open-ended, a matter for ARAZI (and other agencies as relevant) to determine (Article 62[2]).

New articles now allow a lessee to transfer leased land to a third party (Article 76) and for the creation of an Auction Commission to lease out state land (Article 79). In practice, many lands are leased through presidential order. Article 102 in Final Provisions (as if a late thought) limits use of transferred land for uses other than agreed. This responds to popular knowledge that some persons obtain land by order of the President for farming but use the land for the construction of lucrative housing estates. New Article 78 excludes protected areas, areas under international agreement (e.g. military bases), mines or historical monuments, areas of pasture and grazing and "areas of public lands" from allocation to investors.

Such limitations are not new; Article 46 mentioned above is a longstanding provision. This has not prevented these lands from being interfered with, including through increasingly ubiquitous presidential decrees, presented as if they are routine administrative orders, implementing substantial presidential prerogative. The above-mentioned overlap of virgin, arid and rangeland resources compounds the vulnerability of these lands to involuntary

45 Registration of transfers free of charge was already part of the law but is now relocated as new Article 48. loss by local populations. Articles 47 and 62(2) firmly identify arid and virgin lands as available for allocation to investors.

\subsection{There remain chronic problems around the definition of public lands}

The treatment of public lands in general is opaque, exemplified by the extraordinarily short Chapter Nine on this subject (Articles 81-86). The proposed new Articles 84-86 are limited to rights to own trees and cultivate on endowed lands (these being lands donated to the state). The distinction of General Public Land and Special Local Public Land (Special Mar'aa) in Chapter One promised thorough development in the main body of the law but this is not forthcoming. In fact, Chapter Nine fails to even mention Special Mar' aa. This leaves up to 30,000 rural communities uncertain of the status of these lands. This would have been the place to develop not just respect of these lands for local communal use but opportunities for communities to seek formal recognition of these lands as their private, collectively owned properties, albeit with conditions such as not permitting these lands to be sold and for them to be sustainably used.

\subsection{Measures against land-grabbing lack bite}

Chapter Ten is a dedicated new chapter on land grabbing (Articles 87-94). This places the issue in the legal domain but its contents do not strike at the heart of it.

Provincial governments are rightfully ordered to act on identifying grabbed lands and land grabbers (Article 87) but no mechanism is provided for this to be undertaken alongside communities. There are no invitations to the public to submit complaints. One commentator on the law suggested an ombudsman's office be established to deal independently with claims. ${ }^{46}$

It is also disappointing that new provisions focus so singularly upon dealing with grabbed lands presumed to be state lands, when many land grabbings affect community lands

46 McAuslan, "Land Management Law of the Islamic Republic of Afghanistan." 
and are grabbed by state actors themselves. Disincentives in the form of short prison sentences (Articles 90 and 95) are mild. No measures are instituted to limit collusion by officials, the courts or other power holders, such as subjecting their decisions, documentation and issued entitlements to random inspection and harsh punishment for transgressions. J ust as important, the paradigms of what is legal and illegal, and where land should be considered grabbed or informally occupied but with reason, are not discussed in the law. This is puzzling because the need to distinguish between persons who occupy state or public lands as a matter of necessity and those who purposely grab lands to develop for considerable personal benefit is quite well acknowledged in the public domainand a subject of the NLP.

\subsection{The new law is not pro-poor}

There is a range of ways in which the new draft of the LML is not pro-poor. For example, the proposed revisions do not act to secure the rights of tenants and sharecroppers as directed by the NLP (Policy 2.1.1); do not provide properly for community lands (Policy 2.2.1); do not provide for family tenure, leaving gender and generational relations vaguely treated and without legal need to be fairer; do not resolve the troubling competing nature of rights by the state and people to so-called arid, virgin and pasture lands; do not improve the poor mechanisms for identifying and allocating lands for IDPs, returnees and latterly Kuchis; and do not create a land trust to facilitate land allocations to the poor at scale (Policy 3.1.4).

Positive discrimination for women, vulnerable groups and the poor is not provided anywhere in the law, which remains overwhelmingly biased toward enabling the allocation of public and government lands to private interests. Those without documents for their lands-the majority of citizens-are still left without clear routes to remedy this in simple, accessible, affordable and transparent ways. Indeed, their rights are even more constrained in that they have to be able to trace their rights back to the 1960s (Article 8[1]) to secure recognition, presuming they have the means to launch that process. The law still fails to protect the poor against undue eviction and loss of moveable and immoveable property.
Two other problems affecting poor citizens need recapping here. Firstly, informal dispute resolution gets no support from the law. This is necessary given the time and financial costs of using the courts, especially given concerns about prevalent corruption. More legal force needs to be given to decisions at arbitration, mediation and informal and hybrid dispute resolution procedures involving officials. However, this too will be unhelpful unless cheap and accessible opportunities to appeal against decisions made through bribery and corruption are also embedded in the law, perhaps through an ombudsman's office provided by civil society actors in every district-a tall order that would take some working through to be acceptable.

Secondly, as also noted earlier, the failure to attend to tenure and governance needs of millions of informal settlers in towns is a major impediment to a pro-poor land management law. Distinguishing between these people and land grabbers is not so difficult at the local level, illustrating another reason why incremental movements toward inclusive and communitybased decision making are desirable. Poor people in towns need:

1) Improved acknowledgement when they hold legitimate if undocumented rights

2) For those living on the edges of towns and cities, protection against loss of their lands through allocations of those areas for private housing estates

3) Changes to the law that make private housing schemes legal on clearly laid out conditions, including an obligation to include low-cost housing along with public service areas and facilities

4) Much stronger support for variously tested forms of provisional entitlement, pending final verification and recordation of ownership rights

\subsection{Land administration remains inaccessible to the majority}

At the heart of many problems lies the structural failure of the proposed revisions to radically improve the way that the certification of rights to land and houses is undertaken. In 
fact, there does not seem to be an intention to extend availability of rights recognition beyond ad hoc clarification processes driven by the demands of richer people and investors for more land. This would not matter if existing substantial occupancy were awarded explicit and full protection in the absence of "legally valid documentation."

However, without either measure, the land rights of most Afghans are left in uncertain territory. Are their unrecorded rights protected or not? Or does protection still rely upon using the still-remote procedures for acquiring legal documents of ownership? We cannot say.

The need to restructure the land governance system in Afghanistan remains the single most important shift needed in the LML. All aspects of land relations depend upon making the system for identifying rights and the system for making decisions about rights to land much more available to the population.

A devolutionary approach is required by which the central government begins to surrender powers and duties to local levels and invests heavily in building upon the institutions and capacity of ordinary citizens to take on these roles. Village and neighbourhood land councils seem the obvious eventual institutional output, with state agencies (led by ARAZI) taking a role in guiding, monitoring and regulating those actors.

This is not a radical vision, either internationally or in Afghanistan itself.

The national policy that received the blessing of the Council of Ministers in 2007 directed that the system of recording land interests officially be "simplified, localised, made accessible and transparent, less costly, efficient, and more accountable to land owners" (Policy 3.1.2). Other policy directives aimed at the democratisation of land governance were that:

- Sufficient tenure forms be developed to capture all legitimate rights (2.1.1)

- Procedures for state land allocation be equitable, transparent and precise (2.1.2)
- Land be classified as government and private, but also as public and community lands (2.2.1)

- The institutional framework for land governance integrate formal and informal tenure systems (2.2.2)

- Land administration function at district, provincial and national levels (2.2.3)

- Land survey be reactivated to clarify contested rights to pasturelands (2.2.6)

- Community-based adjudication referenced to clarify rights (2.2.7)

- Overlapping roles and conflicting agendas of agencies involved in land administration be removed, and administration as a whole consolidated into a single government body (3.1.2)

- Function of the courts be focused on resolution of disputes (3.1.2)

In some ways, the LML revisions move in these directions. However, the fundamental instrument, devolution to at least district level along with systems that build increasingly upon community-based land administration, is not pursued at all. A community role in the identification of rights, the most basic function of land management, is not provided for. Nor is there any move in the law to curtail the role of the courts in issuing land documents, a major cause of partiality in resolving disputes linked to court-issued documents and a major source of rent-seeking by court officials. Identification of rights, adjudication, certification and registration following survey are not comprehensively laid out, ${ }^{47}$ and there are no provisions entered into the law to simplify procedures or heighten mass access. ${ }^{48}$

As discussed, there are signs that the amendment drafters have not taken the directives of the NLP into account. It is difficult to tell if this is deliberate or the result of an unawareness of its existence. In either case, the directives of the Cabinet-ratified policy now need to be taken into account before the draft is finalised.

\footnotetext{
47 As noted earlier, only survey procedure gets significant treatment in the law.

48 Registration of transactions continues to be free, as in the past, to encourage registration.
} 


\section{Testing the Changes against the National Land Policy}

Broadly, the proposed changes to the LML do not meet best international practice. Nor do they meet the stated objectives and principles of Afghanistan's own land policy of 2007. Specific directives of the NLP are also very erratically met.
Table 2 lists the objectives and principles of the NLP that preface its statements, and assesses whether the proposed amendments that are serving as the basis of public consultation meet these.

Table 2: Comparing the Land Law Proposals with the National Land Policy (2007)

\begin{tabular}{|c|c|c|}
\hline \multicolumn{2}{|r|}{ Policy Objective } & Does the Draft Land Management Law 2012 Meet the Objective? \\
\hline 1 & $\begin{array}{l}\text { Provide every Afghan access } \\
\text { to land }\end{array}$ & $\begin{array}{l}\text { The revisions meet this only in theory. The law does not make it obligatory for } \\
\text { the state to act to achieve this, only providing the opportunity for it to do so at } \\
\text { its will. }\end{array}$ \\
\hline 2 & $\begin{array}{l}\text { Promote and ensure a secure } \\
\text { land tenure system }\end{array}$ & $\begin{array}{l}\text { This is not met; the law does not provide a comprehensive system that } \\
\text { assures access to tenure. Nor does it ensure sanctity of title through credible } \\
\text { mechanisms for incorruptibility. }\end{array}$ \\
\hline 3 & $\begin{array}{l}\text { Encourage the optimal use of } \\
\text { land }\end{array}$ & $\begin{array}{l}\text { The law attempts this but through effectively reserving access to arid and virgin } \\
\text { lands for investors it raises questions of existing rights over those lands, and in } \\
\text { turn questions of equity and justice. }\end{array}$ \\
\hline 4 & $\begin{array}{l}\text { Establish an efficient system } \\
\text { of land administration }\end{array}$ & $\begin{array}{l}\text { The system remains unchanged and still fails to capture the majority of rights } \\
\text { under a viable and inclusive recognition and protection system, which is the } \\
\text { objective of land administration. }\end{array}$ \\
\hline 5 & $\begin{array}{l}\text { Ensure that land markets } \\
\text { are efficient, equitable, } \\
\text { environmentally sound, } \\
\text { sustainable, improve } \\
\text { productivity, and alleviate } \\
\text { poverty }\end{array}$ & $\begin{array}{l}\text { Lands can be freely sold but the law does not provide measures that would lead } \\
\text { to these outputs, particularly the alleviation of poverty. The revisions do set } \\
\text { aside protected areas as unavailable for lease, which is a positive step toward } \\
\text { environmental soundness. }\end{array}$ \\
\hline & Policy Principle & Does the Draft Land Management Law 2012 Achieve this? \\
\hline 1 & $\begin{array}{l}\text { Serve diverse interests of } \\
\text { society }\end{array}$ & $\begin{array}{l}\text { The law attempts to encompass diverse rights to land but in weak and uneven } \\
\text { ways. For example, the state is not obliged to provide land to the landless and } \\
\text { opens the way for existing landholders to be allocated (more) lands. The maj or } \\
\text { interest of communities to secure pastures as their rightful property is ignored. } \\
\text { The proposed revisions are silent on protection requirements of farm tenants, } \\
\text { sharecroppers, workers and those who have been forced to mortgage their land } \\
\text { to mainly landlords. The law is also silent on the needs of several million urban } \\
\text { poor who have no security of tenure in so-called informal settlements. No plan } \\
\text { to regularise their rights is embedded in the law. }\end{array}$ \\
\hline 2 & $\begin{array}{l}\text { Land must be preserved for } \\
\text { future generations }\end{array}$ & $\begin{array}{l}\text { The law acknowledges that protected areas exist but provides no system of } \\
\text { planning for land use through which these will be identified in fair and inclusive } \\
\text { ways. Existing MAIL policy toward community-based resource management is } \\
\text { entirely ignored. }\end{array}$ \\
\hline
\end{tabular}




\begin{tabular}{|c|c|c|}
\hline 3 & $\begin{array}{l}\text { No individual or group to be } \\
\text { barred from ownership }\end{array}$ & $\begin{array}{l}\text { In principle this is provided for in the law but procedural mechanisms for } \\
\text { ensuring it are lacking. Common property ownership is not properly tackled. }\end{array}$ \\
\hline 4 & $\begin{array}{l}\text { Land is the most important } \\
\text { resource for achieving } \\
\text { constitutional commitments }\end{array}$ & $\begin{array}{l}\text { It is not evident that this perspective has specifically shaped the law. In any } \\
\text { event, it is more declamatory than instructive. }\end{array}$ \\
\hline 5 & $\begin{array}{l}\text { Institutional coherence and } \\
\text { efficiency }\end{array}$ & $\begin{array}{l}\text { Proposed amendments to the law fail to deliver on this. The "one stop shop" } \\
\text { policy is not fully developed institutionally, no legal instructions are proposed } \\
\text { as to the reduction of procedures in land transfers, simplification of acquiring } \\
\text { legal documents, or devolving services so that they are directly available- } \\
\text { and accountable-to the maj ority. The troubling role of the courts in land } \\
\text { administration remains untouched. }\end{array}$ \\
\hline 6 & $\begin{array}{l}\text { The system is to be } \\
\text { transparent, accountable and } \\
\text { to involve communities }\end{array}$ & $\begin{array}{l}\text { The regime presented is only a little different from the currently operating } \\
\text { system, which has shown itself susceptible to corruption and unaccountable to } \\
\text { the public, and does not institutionally involve communities. }\end{array}$ \\
\hline 7 & $\begin{array}{l}\text { There are to be no land- } \\
\text { related legal impediments } \\
\text { created or permitted on the } \\
\text { basis of gender, language, } \\
\text { religion or marital status }\end{array}$ & Expected positive discrimination in procedures is not provided. \\
\hline 8 & $\begin{array}{l}\text { The private sector is the } \\
\text { key to economic growth and } \\
\text { must be enabled to acquire } \\
\text { enforceable and transferable } \\
\text { rights }\end{array}$ & This is provided for in the draft law. \\
\hline 9 & $\begin{array}{l}\text { A transparent land market is } \\
\text { to be promoted }\end{array}$ & $\begin{array}{l}\text { The law offers no constraints to a land market, but measures to ensure it } \\
\text { is transparent are weak, mainly centring on threats of imprisonment for } \\
\text { apprehended land grabbers. }\end{array}$ \\
\hline 10 & $\begin{array}{l}\text { All use rights are to be } \\
\text { formally recognised and } \\
\text { protected }\end{array}$ & $\begin{array}{l}\text { The proposed amendments make no real progress toward this. Special Mar' aa } \\
\text { is provided for (as already exists but without this term) but the procedure for } \\
\text { identifying areas designated for community use is not entered into the law. } \\
\text { Nor are legally binding steps provided to unpack and resolve contested rights } \\
\text { between settled and nomadic communities. The basic structural change to } \\
\text { tenure needed for this is also not provided; there is a need to enable local } \\
\text { communities to be recognised as owners of pastures but bound to consider } \\
\text { seasonal access rights of specific groups of nomads where a long history of access } \\
\text { to the particular pasture can be demonstrated. }\end{array}$ \\
\hline 11 & $\begin{array}{l}\text { Information on rights publicly } \\
\text { accessible }\end{array}$ & $\begin{array}{l}\text { The proposed law makes no new provisions as to public availability of all } \\
\text { information relating to landholdings and transactions. }\end{array}$ \\
\hline 12 & $\begin{array}{l}\text { Land rights to be transferable } \\
\text { for payment }\end{array}$ & This is achieved in that the law institutes no new impediments. \\
\hline 13 & Rights can be taxable & This is provided for. \\
\hline 14 & $\begin{array}{l}\text { Government will distribute } \\
\text { land fairly }\end{array}$ & The law makes this possible but not obligatory. \\
\hline
\end{tabular}




\section{Conclusions}

In summary, the proposed amendments do not yet make much change to the LML of 2008. Tenure categories are still insufficient to cater to actual landholding patterns. Land governance remains centralised and inaccessible to the majority, inhibiting access to procedures for identifying and formalising rights. The historical bias of the law in favour of rural communities continues, leaving urban tenure and governance concerns weakly covered. The opportunity is missed to lay down legally-binding procedures through which so-called informal settlers can secure their properties at the same time as wrongful land grabbers are brought to book. The tenure status quo is not altered, leaving the state still firmly the real or de facto legal owner of thousands of hectares of lands that are more rightfully community properties. Meanwhile, investors, not ordinary citizens, are legally favoured in accessing formal allocations to virgin and arid lands, which in practice overlap rangelands historically owned and currently used by poor communities.

A number of new provisions are well intentioned but fall short of delivering concrete legal remedies to old problems. Land grabbers are threatened with punishment but there are no procedural teeth behind this. The law is silent on the role that excessive presidential prerogative over land allocation plays in facilitating land grabbing. Indeed, presidential power is reinforced with a possible belief that this is the way to aid transparency, which is not borne out in visible practice. The new law is also silent on the chronic problem of conflicts of interest for courts engendered through their dual role as land registries as well as sources of conflict resolution. Highly contested rights between settled and nomadic communities remain untouched by required legal procedure and remedy that restructure how rangelands are owned and accessed. Land administration, the core of the $L M L$, is not reformed. The system remains overly centralised and undemocratic, pursuing high-cost titling procedures that constrain workability at scale, sustainability and citizen uptake. The law still leaves the majority who have weak or no documentary evidence of ownership in uncertain positions. Rights identification procedures are not made directly available to communities in cheap or accountable ways. Vulnerable sectors such as women, returnees, IDPs, tenants, sharecroppers and those living in informal settlements make no gains in the proposed changes to the law.

There is still scope for more amendments to the basic LML to be made. In this respect, the Afghan government is at a crossroads. In legal terms it may remain with this slightly modified text or consider a more genuinely reformed approach to land management. In terms of substance, it may remain with a centralised and inaccessible model, or lay down paths toward more workable, inclusive and fair norms of tenure and governance affecting the majority of citizens. At this point, the law can be accused of serving elites, investors and lessees, and not the ordinary poorer citizen. Suggestions for shifting the focus are presented below.

\section{Recommendations}

Ideally, the LML as it stands would be redrafted in its entirety. In this event, the starting point would be to build upon the pledges of the NLP and best international practice in land administration.

This is unlikely to occur, at least in the short term. The logical compromise is therefore to continue improving the text toward democratic workability of land administration and pro-majority justice in terms of tenure. Both process and substance need attention.

\subsection{Procedure}

\section{Adopting an incremental approach}

Even if the major shifts required cannot be accomplished by further redrafting, it is critical that the final changes submitted to the Cabinet and parliament have a fully reformed vision of land rights and governance in mind and open paths to this. For example, much more recognition is needed of ways that poor informal 
settlers can at least get provisional entitlement. More building blocks are also needed in the law to at least enable consideration of a more community-based system for land adjudication and recordation to occur.

\section{Popularising the law for enhanced public ownership and use}

Making the law directly available to the populace is critical to modern, fair and accessible land law. This includes the preparation of simple information sheets explaining the law and people's rights within the law that could be distributed to every village and neighbourhood in the country. Such products are also essential for policy and decision-makers including members of parliament. Such steps not only respect the public right to information and knowledge but also do much to inform and nurture the public awareness and demand needed to drive official and judicial integrity.

\subsection{Substance}

The most immediate changes recommended to the substance of the law are new articles that:

1) Subject future allocations of state or public lands to localised and participatory discovery of existing rights with communities. Such inspection or clarification exercises must consider all rights that are undocumented, including those that are held collectively by groups and communities to off-farm lands. A public call for submissions and attendance at meetings will be imperative. A fair timeline against which such claims are accepted needs to be introduced. This needs to bear in mind the enormous upheavals and internal migrations that characterise settlement today.

2) Place limits upon what could be interpreted as undue presidential privilege by requiring that proposed allocations or land grants above 100 jeribs be submitted to parliament for approval.

3) Provide more fully for community lands. This should be done by elaborating how community rights to public lands are identified and defined (Special Mar'aa) and by providing opportunity in the law for individual communities to apply for recognition as owners of certain lands, which can be awarded on particular conditions, including that those properties not be sold.

4) Provide explicitly for communities to be considered as legal persons for the purposes of this law, to enable communities to own registrable property in their own right, as above.

5) Develop cheap, accessible and fair opportunities for informal settlers in towns to secure at least provisional entitlement when it is shown that that they have not grabbed land to profit commercially.

6) Provide unambiguous protection of occupancy rights to persons, families and communities who have lived on and used parcels for a reasonable period of time (1989 is suggested); treat this as provisional entitlement, documented or otherwise.

7) Provide simple legal guidance as to how a community can voluntarily carry out fully inclusive community-based identification, adjudication and recordation of all rights affecting its village or neighbourhood area, as a first no-cost step toward increasing recordation of rights nationwide. This approach necessarily involves agreement with neighbouring communities of the limits of their respective community land areas. The records they produce, including minutes signed by most community members as to the process followed, should follow a simple, common-sense format that has been prepared by ARAZI and distributed to every village and neighbourhood in the country. The records should be subject to scrutiny and confirmation as necessary by a team appointed in every district for this purpose. The results should form the basis of a provisional district register of land ownership and use rights to public lands, and be copied into central records.

8) Modify the state-conducted and surveybased clarification process (tasfeya) in light of the above. This means reconstructing the process so that it begins with the above community-based approach, including 
adjudication with neighbouring communities where collectively-owned lands adjoin.

9) Make space in the revised law to allow for the incremental development of Community Land Councils, which will over time be gradually mandated with more duties and powers, depending upon performance. Provisions for this will need to be built in coordination with local government development and, in particular, the planned evolution of elected village land and neighbourhood councils

10) Introduce provisions for spot-checks by third-party agencies of the performance and accountability of all officials, departments and agencies with land-related duties and powers.

11) Amend the LML (and the Land Acquisition Law) to better balance pro-poor and maj ority land needs with private commercial developments by:

- Requiring all future allocations of state or public lands to private commercial developments be conditional upon an agreement to provide specific numbers of jobs and other measures designed to help alleviate the landlessness and livelihood stresses of IDPs, returnees and other poor population sectors in the immediate area.

- Making it law that compensation be paid to evictees not only for lost homes and farms but also for the value of rangelands that the affected community has traditionally owned in common and remained dependent upon.

- Limiting arbitrary eviction by making it legally binding to follow carefully listed procedures and conditions when occupied or used land is taken for public purposes or allocated to commercial developers.

Finally, it is suggested that the drafters introduce a commitment to the objectives and principles of the National Land Policy and the directives it lays down. The amended law should also state that land administrators and the courts are legally bound to take these into account when making decisions affecting the land rights of citizens. 


\section{Request for Feedback}

Funding for this research has been made possible by the United States Institute of Peace.

AREU is very interested to hear from its research users. Whether you are a regular reader of our publications, have attended an AREU lecture or workshop, use the library, or have only just become familiar with the organisation, your opinions and feedback are valuable. They can help us deliver on our mandate as best we can by informing our approach to research and the way we communicate results. The easiest way to provide feedback is to email areu@areu.org. af. Alternatively, you can call t93 (0)799 608 548. You are free to tell us what you like, but some potentially useful information is:

- How you engage with AREU (i.e., through publications, meetings, etc.)

- What you use AREU research for

- How you receive AREU publications

- Whether you use hard or soft copy versions

- How publications could better present information to you

- Your thoughts on our research processes or results

- Suggested areas of research

- Your favourite AREU publications or events

- What you believe we could do better

- Your field of interest, employment or study, as well as location 


\section{Recent Publications from AREU}

J uly 2012 \#Fixing Afghanistan's Electoral System: Arguments and Options for Reform, by Andrew Reynolds and J ohn Carey

J une 2012 The Impact of Microfinance Programmes on Women's Lives: A Case Study in Balkh Province, by Chona R. Echavez, with Sogol Zand and J ennefer Lyn L. Bagaporo

J une 2012 Mind the Gap? Local practices and institutional reforms for water allocation in Afghanistan's Panj-Amu River Basin, by Vincent Thomas, with Wamiqullah Mumtaz and Mujib Ahmad Azizi

May 2012 \#The 2012 A to Z Guide to Afghanistan Assistance

April 2012 Does Women's Participation in the National Solidarity Programme Make a Difference in their Lives? A Case Study in Kabul Province, by Chona R. Echavez

March 2012 Gender and Economic Choice: What's Old and What's New for Women in Afghanistan? by Chona R. Echavez

March 2012 \#Equal Rights, Unequal Opportunities: Women's Participation in Afghanistan's Parliamentary and Provincial Council Elections, by Oliver Lough, with Farkhloqa Amini, Farid Ahmad Bayat, Zia Hussein, Reyhaneh Gulsun Husseini, Massouda Kohistani and Chona R. Echavez

March 2012 Does Women's Participation in the National Solidarity Programme Make a Difference in their Lives? A Case Study in Balkh Province, by Chona R. Echavez with J ennefer Lyn L. Bagaporo

J an 2012 Thirty Years of Conflict: Drivers of Anti-Government Mobilisation in Afghanistan, by Antonio Giustozzi with Niamatullah Ibrahimi

\# Indicates that the publication or a summary is or will be available in Dari and/ or Pashto

The Afghanistan Research and Evaluation Unit (AREU) is an independent research institute based in Kabul. AREU's mission is to inform and influence policy and practice through conducting high-quality, policy-relevant research and actively disseminating the results, and to promote a culture of research and learning. To achieve its mission AREU engages with policymakers, civil society, researchers and students to promote their use of AREU's research and its library, to strengthen their research capacity, and to create opportunities for analysis, reflection and debate.

AREU publications are available for download at www. areu. org. af and in hardcopy from the AREU office: House 649, Third Street on the right, Haji Yacoub Sq. toward Shaheed Sq.

Shahr-i-Naw, Kabul, Afghanistan

phone: +93 (0) 799608548 website: www.areu.org.af email: publications@areu.org.af

(C) 2012 Afghanistan Research and Evaluation Unit. Some rights reserved. This publication may be reproduced, stored in a retrieval system or transmitted only for non-commercial purposes and with written credit to AREU and the author. Where this publication is reproduced, stored or transmitted electronically, a link to AREU's website (www. areu. org. af) should be provided. Any use of this publication falling outside of these permissions requires prior written permission of the publisher, the Afghanistan Research and Evaluation Unit. Permission can be sought by emailing areu@areu. org. af or by calling +93 (0) 799608548. 